Original Research Paper

\title{
Effects of Short Term in vitro Stress Hormone Exposure on Regulatory T Cell Number and Function in Asthma
}

\author{
Kristina E. Rehm and Gailen D. Marshall, Jr. \\ Laboratory of Behavioral Immunology Research, Division of Clinical Immunology and Allergy, \\ Department of Medicine, University of Mississippi Medical Center, Jackson, MS
}

\section{Article history}

Received: 01-12-2014

Revised: 19-04-2015

Accepted: 21-04-2015

Corresponding Author:

Kristina E. Rehm

Laboratory of Behavioral

Immunology Research, Division of

Clinical Immunology and Allergy,

Department of Medicine,

University of Mississippi Medical

Center, 2500 North State Street -

N416, Jackson, MS 39216

Tel: 601-815-5527

Fax: 601-815-4770

Email:krehm@umc.edu

\begin{abstract}
Asthma is characterized by alterations in the immune system, including regulatory $T$ cells $\left(T_{\text {reg }}\right)$. Further alterations in $T_{\text {reg }}$ numbers and/or function caused by stress hormones may be a contributing factor in asthma pathogenesis. We compared $T_{\text {reg }}$ populations and the effects of Dexamethasone (DEX, a laboratory analog of cortisol) on $\mathrm{T}_{\text {reg }}$ cell number and function in patients with asthma and a control group. We isolated Peripheral Blood Mononuclear Cells (PBMC) from asthma patients $(\mathrm{n}=7)$ and normal controls $(\mathrm{n}=8)$ and quantified $\mathrm{CD}^{+}$, $\mathrm{CD} 4^{+} \mathrm{CD} 25^{\text {hi }}$ and $\mathrm{CD} 4^{+} \mathrm{CD} 25^{\text {hi }} \mathrm{FoxP}^{+} \mathrm{T}$ cells by flow cytometry. To determine the effects of in vitro stress hormones on $\mathrm{T}_{\text {reg }}$ number and function, we incubated PBMC with $10^{-9} \mathrm{M}, 10^{-8} \mathrm{M}$ and $10^{-7} \mathrm{M}$ DEX for $24 \mathrm{~h}$ and then $\mathrm{CD} 4{ }^{+} \mathrm{CD} 25^{\mathrm{hi}} \mathrm{FoxP}^{+} \mathrm{T}_{\text {reg }}$ were quantified by flow cytometry. To assess function, $\mathrm{CD} 4^{+} \mathrm{CD} 25^{+}$were separated and added to cultures of bead-stimulated $\mathrm{CD}^{+} \mathrm{CD} 25^{-}$cells and proliferation was measured and compared to the $\mathrm{CD} 4^{+} \mathrm{CD} 25^{-}$cultures incubated with beads alone. The asthma group had significantly fewer $\mathrm{CD} 4^{+} \mathrm{CD} 25^{\text {hi }}$ and $\mathrm{CD} 4{ }^{+} \mathrm{CD} 25^{\text {hi }}{ }^{\mathrm{F} o x P} 3^{+}$cells than the control group. DEX significantly decreased $\mathrm{T}_{\text {reg }}$ number in the control group but not in the asthma group. DEX had no effect on $\mathrm{CD}^{+} \mathrm{CD} 25^{+}$function in either group and the suppressive capacity of the $\mathrm{CD} 4^{+} \mathrm{CD} 25^{+}$cells was no different between the asthma group and the normal control group. These data suggest that while asthmatics have fewer $T_{\text {reg }}$ than normal controls, their function does not differ. These data also suggest that $\mathrm{T}_{\text {reg }}$ from asthmatics may be less susceptible to the effects of stress hormones.
\end{abstract}

Keywords: Regulatory T Cell, Stress, Asthma, Function

\section{Introduction}

Asthma is an inflammatory airway disease characterized by reversible airway obstruction and bronchial hyper responsiveness to typically innocuous environmental stimuli (Kudo et al., 2013). Current data indicate that asthma affects more than 300 million people worldwide (Murdoch and Lloyd, 2010). Risk factors for the development of asthma include certain genetic factors (Lockett and Holloway, 2013), elevated serum IgE levels (Hayden, 2007), obesity (Baumann and Lorentz, 2013), cigarette smoking (Thomson et al., 2004), environmental stress (Brooks et al., 2013) and psychological stress (Chen et al., 2006). Mediators of asthma exacerbations include numerous cells of the immune system including eosinophils, mast cells, the IL4-producing Th2 cells and $\mathrm{FoxP}^{+}$regulatory $\mathrm{T}$ cells (Holgate, 2013).

Regulatory $\mathrm{T}$ cells $\left(\mathrm{T}_{\text {reg }}\right)$ are specialized $\mathrm{CD} 4^{+}$cells that regulate the intensity and duration of immune responses to a variety of antigens (Sakaguchi et al., 2009) and are thought to play a key role in the pathogenesis of asthma (Ray et al., 2010). $\mathrm{T}_{\text {reg }}$ can regulate both Th1 (intracellular/anti-viral) and Th2 (extracellular/anti-allergen) responses (Ray et al., 2010). FoxP3, an intracellular transcription factor and high levels of the surface antigen CD25 are the most specific markers for $\mathrm{T}_{\text {reg }}$ (Vent-Schmidt et al., 2013). FoxP3 controls both the development and function of $\mathrm{T}_{\text {reg }}$ (Vent-Schmidt et al., 2013). A complete absence of 
FoxP3 expression results in severe autoimmunity and inflammation in both mice and man (Ray et al., 2010). Less severe alterations in FoxP3 numbers and/or function have also been reported in numerous other diseases, including asthma, although the data are conflicting. Some studies report a decrease in $\mathrm{T}_{\text {reg }}$ number and function in asthma patients (Provoost et al., 2009; Hartl et al., 2007) compared to normal controls while others report no difference (Shi et al., 2004; Bellinghausen et al., 2003). Comparisons between studies are difficult due to differences in asthma phenotypes, differences in defining the $\mathrm{T}_{\text {reg }}$ population and the nature of the stimulation used in the functional assays.

Psychological stress has been implicated in the etiology and severity of inflammatory-based diseases, including asthma (Pokladnikova and Selke-Krulichova, 2013; Chen and Miller, 2007). Psychological stress induces the production of corticosteroids which are potent immunoregulators. Data from our lab indicate that short-term exposure to stress equivalent physiologic doses of Dexamethasone (DEX), a laboratory analog of cortisol, results in a decrease in IFN $\gamma$ (a Th1 cytokine) production and an increase in IL4 (a Th2 cytokine) production (Salicru et al., 2007), which is mechanistically consistent with the observation that stress can cause asthma exacerbations. A potential mechanism for the stress-induced alterations to IFN $\gamma$ and IL4 is changes to $T_{\text {reg }}$ number and/or function since these cells can control the responses to various effector $\mathrm{T}$ cell populations (Ray et al., 2010). We recently reported that short-term DEX exposure resulted in a decrease in FoxP3 mRNA expression in healthy subjects (Xiang and Marshall, 2011). The effect of short term exposure of stressphysiologic doses of DEX on $\mathrm{T}_{\text {reg }}$ protein expression and function in asthmatic patients is not known.

Here we compared various $\mathrm{CD}^{+} \mathrm{T}$ cell populations in an asthmatic population with healthy controls. In addition, we sought to compare the effects of DEX on both $\mathrm{T}_{\text {reg }}$ numbers and function between asthmatics and healthy controls. An increased understanding of the effects of psychological stress on the cellular mechanisms that contribute to asthma pathogenesis can aid in the development of novel therapies targeted at reducing the occurrence and severity of asthma exacerbations in susceptible populations.

\section{Materials and Methods}

\section{Subject Selection}

Volunteers (asthma $\mathrm{n}=7$, healthy $\mathrm{n}=8$ ) were recruited after obtaining written informed consent according to a University of Mississippi Medical Center
Institutional Review Board approved protocol. In addition, all procedures were in accordance with the Helsinki Declaration of 1975. The characteristics of the population are shown in Table 1 . Characteristics of the asthmatic population were not significantly different from the control population. Subjects were excluded for any past medical history of smoking, psychiatric illnesses, cardiovascular diseases, autoimmune diseases, or recent medical use (within the past 30 days) of systemic glucocorticoids, high dose inhaled corticosteroids, catecholamines and/or adrenergic antagonists. Asthma was confirmed by positive answer to the question: "Have you been told by a physician that you have asthma?"

\section{PBMC Isolation}

Venous blood was collected into heparinized tubes and PBMC were isolated using a ficoll-hypaque gradient as previously described (Rehm et al., 2012). Briefly, cells were centrifuged at $650 \mathrm{~g}$ for $30 \mathrm{~min}$, washed twice in HBSS and then resuspended in $1 \mathrm{~mL}$ cRPMI supplemented with 5\% FBS. Cell counts were obtained using an automated hematology analyzer.

\section{PBMC Cultures}

Isolated PBMC were split into four equal groups and incubated either without DEX, or with DEX at concentrations of $10^{-7}, 10^{-8}$ and $10^{-9} \mathrm{M}$ (these concentrations are approximately equivalent to pharmacological concentration, stress physiological concentration and physiological concentration, respectively) (Agarwal and Marshall, 1998). Cells were incubated for $24 \mathrm{~h}$ at $37^{\circ} \mathrm{C}, 5 \% \mathrm{CO}_{2}$.

\section{Isolation of $\mathrm{CD}^{+}, \mathrm{CD} 4^{+} \mathrm{CD} 25^{-}, \mathrm{CD} 4^{+} \mathrm{CD} 25^{+}$Cell Populations}

To study $\mathrm{T}_{\text {reg }}$ functionality, total $\mathrm{CD} 4^{+}, \mathrm{CD} 4^{+} \mathrm{CD} 25^{-}$ conventional $\mathrm{T}$ cells and $\mathrm{CD} 4^{+} \mathrm{CD} 25^{+} \mathrm{T}_{\text {reg }}$ were isolated from the PBMC cultured with and without DEX. $\mathrm{CD} 4^{+} \mathrm{CD} 25^{+}$are traditionally used as $\mathrm{T}_{\text {reg }}$ in these assays since it is impossible to isolate cells based on FoxP3 (the most definitive marker for $T_{\text {reg }}$ ) due to its intracellular expression. First, total $\mathrm{CD}^{+} \mathrm{T}$ cells were isolated by negative selection using the Human $\mathrm{CD}^{+} \mathrm{T}$ Cell Isolation Kit per the manufacturer's instructions (Miltenyi Biotech; San Diego, CA). From this $\mathrm{CD}^{+} \mathrm{T}$ cell population, $\mathrm{CD} 25^{-}$and $\mathrm{CD} 25^{+}$cells were separated using Dynal CD25 Microbeads per the manufacturer's instructions (Life Technologies; Grand Island, NY). The purity of all isolated populations was assessed by flow cytometry. A typical isolation using the $\mathrm{CD} 4^{+} \mathrm{T}$ cell Isolation kit was $>95 \% \mathrm{CD}^{+} \mathrm{T}$ cells and a typical isolation using the $\mathrm{CD} 25$ Microbeads resulted in a 
population that was $>85 \% \mathrm{CD} 4^{+} \mathrm{CD} 25^{+}$(data not shown). Cell numbers were determined using an automated hematology analyzer (Coulter).

\section{Proliferation Assay}

To determine the suppressive capacity of the isolated $\mathrm{T}_{\text {reg }}$ cells, a constant number of conventional $\mathrm{T}$ cells $\left(\mathrm{CD} 4^{+} \mathrm{CD} 25^{-}\right)$was added to wells of a round-bottom 96 well plate and then varying numbers of $T_{\text {reg }}$ $\left(\mathrm{CD}^{+} \mathrm{CD} 25^{+}\right)$were added in triplicate. For this paper we used ratios of $1: 1$ and $1: 2$ for $\mathrm{CD} 4^{+} \mathrm{CD} 25^{-}$to $\mathrm{CD} 4^{+} \mathrm{CD} 25^{+}$ cells. The $\mathrm{CD} 4^{+} \mathrm{CD} 25^{-}$cells were stimulated using the $\mathrm{T}$ cell Activation and Expansion Kit (Miltenyi Biotech; San Diego, CA). Anti-biotin beads were pre-loaded with antibodies to CD2, CD3 and CD28 (5 $\mu$ g per antibody per $1 \mathrm{~mL}$ of beads) and were added at a concentration of 1 bead per 1 cell $\mathrm{CD} 4^{+} \mathrm{CD} 25^{-}$. Control wells included $\mathrm{CD} 4^{+} \mathrm{CD} 25^{-}$cells incubated alone with beads, $\mathrm{CD} 4^{+} \mathrm{CD} 25^{+}$cells incubated alone with beads, $\mathrm{CD} 4^{+} \mathrm{CD} 25^{-}$and $\mathrm{CD} 4^{+} \mathrm{CD} 25^{+}$cells incubated alone with no beads and media only. The plate was incubated for 3 days, at which time $10 \mu \mathrm{L}$ of MTS/PMS $\left(2 \mathrm{mg} \mathrm{mL}^{-1}\right.$ MTS, $0.1 \mathrm{mg} \mathrm{mL}^{-1} \mathrm{PMS}$; Promega) was added, followed by an additional $24 \mathrm{~h}$ incubation at $37^{\circ} \mathrm{C}$ and $5 \% \mathrm{CO}_{2}$ (Rehm et al., 2010). The colored product that is produced by proliferating cells was then read on a spectrophotometer at $490 \mathrm{~nm}$.

\section{Flow Cytometry}

Cell populations were analyzed for expression of CD4, CD25 and FoxP3. Cell populations were incubated for 30 min with surface antibodies for CD4 and CD25, washed in flow buffer and fixed with $1 \%$ Paraformaldehyde (PFA). For detection of FoxP3, fixed cells were washed and then resuspended in permeabilization buffer $(0.5 \%$ saponin in $\mathrm{PBS})$ and anti-FoxP3. The cells were then washed and resuspended in 1\% PFA. Positively stained cells were identified by the simultaneous analysis of isotypematched control antibodies. Representative plots are depicted in Fig. 1. First Forward and Side Scatter were used to gate total PBMC (Fig. 1A). PBMC were then analyzed for $\mathrm{CD}^{+}$and $\mathrm{CD} 25^{+}$expression (Fig. 1B). For $\mathrm{CD}^{+}$cells, the total percentage of cells in the $\mathrm{CD}^{+}$gates ( $\mathrm{E}$ and $\mathrm{F}$ on the plot) were added together. The percentage of $\mathrm{CD} 4^{+} \mathrm{CD} 25^{\text {hi }}$ cells were taken from Gate $\mathrm{G}$ (Fig. 1B). To determine the percentage of CD $4{ }^{+} \mathrm{CD} 25^{\text {hi }}$ FoxP3 ${ }^{+}$cells, both the E (Fig. 1C) and $\mathrm{G}$ (Fig. 1D) gates were analyzed for CD25 and FoxP3 expression. Gating for FoxP3 was first done on the $\mathrm{CD} 4^{+} \mathrm{CD} 25^{-}$plot (Fig. 1C) and was set at $10 \%$. Same gating parameters were then set to the $\mathrm{CD} 4^{+} \mathrm{CD} 25^{\text {hi }}$ plot (Fig. 1D). The percentage of $\mathrm{CD} 4{ }^{+} \mathrm{CD} 25^{\mathrm{hi}} \mathrm{FoxP} 3^{+}$was calculated using the following equation:

$$
\frac{\text { Total number of cells FoxP3 } 3^{+} C D 25^{\mathrm{hi}}}{\text { Total number of } C D 4^{+} \text {cells }} \times 100
$$

\section{Statistical Analysis}

Normality was tested using the Shapiro-Wilk test and all data were determined to be normally distributed (data not shown). Descriptive statistics were computed as means (standard deviation) for continuous variables and frequency counts and percentages for categorical variables. Pearson chi square was used to determine statistical differences in categorical variables (race and gender) between groups and a two-tailed independent samples $t$ test was used to compare means of continuous variables between groups. A p value $<0.05$ was considered significant. All statistics were computed with SPSS 22.

\section{Results}

\section{T cell Populations in Asthma and Normal Controls}

We isolated PBMC from 7 asthmatic patients and 8 normal controls and measured various $\mathrm{CD}^{+} \mathrm{T}$ cell subpopulations. Representative flow cytometric plots are shown in Fig. 1 and gating strategy is described in the Materials and Methods section. There was no difference in the percentage of total $\mathrm{CD}^{+} \mathrm{T}$ cells between the normal controls $(53.9 \%)$ and the asthma group (44.6\%; $\mathrm{p}$ $=0.128)$ (Fig. 2A). Asthmatics had significantly less ( $\mathrm{p}=$ $0.002) \mathrm{CD}^{+} \mathrm{CD} 25^{\mathrm{hi}} \mathrm{T}$ cells $(1.3 \%)$ compared to the normal controls (2.4\%) (Fig. 2B). Asthmatic patients also had significantly less $(\mathrm{p}=0.019)$ $\mathrm{CD} 4{ }^{+} \mathrm{CD} 25^{\mathrm{hi}} \mathrm{FoxP}^{+}\left(\mathrm{T}_{\mathrm{reg}}\right)$ in their PBMC (1.86\%) compared to the normal control group (3.2\%) (Fig. 2C).

\section{Effects of Short-Term DEX Incubation on $T_{\text {reg }}$ Populations in Asthmatic and Normal Patients}

Next, we compared the effects of DEX incubation on $\mathrm{T}_{\text {reg }}$ numbers in asthmatics and normal controls (Fig. 3). For normal controls, $24 \mathrm{~h}$ incubation with $10^{-9} \mathrm{M}$ DEX did not result in a significant change in $T_{\text {reg }}$ numbers $(p=$ 0.401 ) but there was a significant decrease in $\mathrm{T}_{\text {reg }}$ after incubation for $24 \mathrm{~h}$ at $10^{-8} \mathrm{M} \mathrm{DEX}$ (from 3.2 to $2.14 \%$; $\mathrm{p}$ $=0.022$ ) and $10^{-7} \mathrm{M} \mathrm{DEX}$ (from 3.2 to $1.6 \% ; \mathrm{p}=0.002$; Fig. 3).On the other hand, there was no significant change in $\mathrm{T}_{\text {reg }}$ in the asthma group after incubation at $10^{-9} \mathrm{M}$ DEX (from 1.86 to $1.7 \% ; \mathrm{p}=0.77$ ), $10^{-8} \mathrm{M}$ DEX (from 1.86 to $1.24 \% ; \mathrm{p}=0.22$ ), or $10^{-7} \mathrm{DEX}$ (from 1.86 to $1.03 \% ; p=0.08$; Fig. 3 ). Asthmatics had significantly less $\mathrm{T}_{\text {reg }}$ compared to the normal controls in the No DEX group (normal: $3.2 \%$ Vs asthma: $1.86 \% ; p=0.019$ ) and after incubation with $10^{-8} \mathrm{M}$ DEX (normal: $2.1 \% \mathrm{Vs}$ asthma: $1.2 \% ; \mathrm{p}=0.032$; Fig. 3 ). 

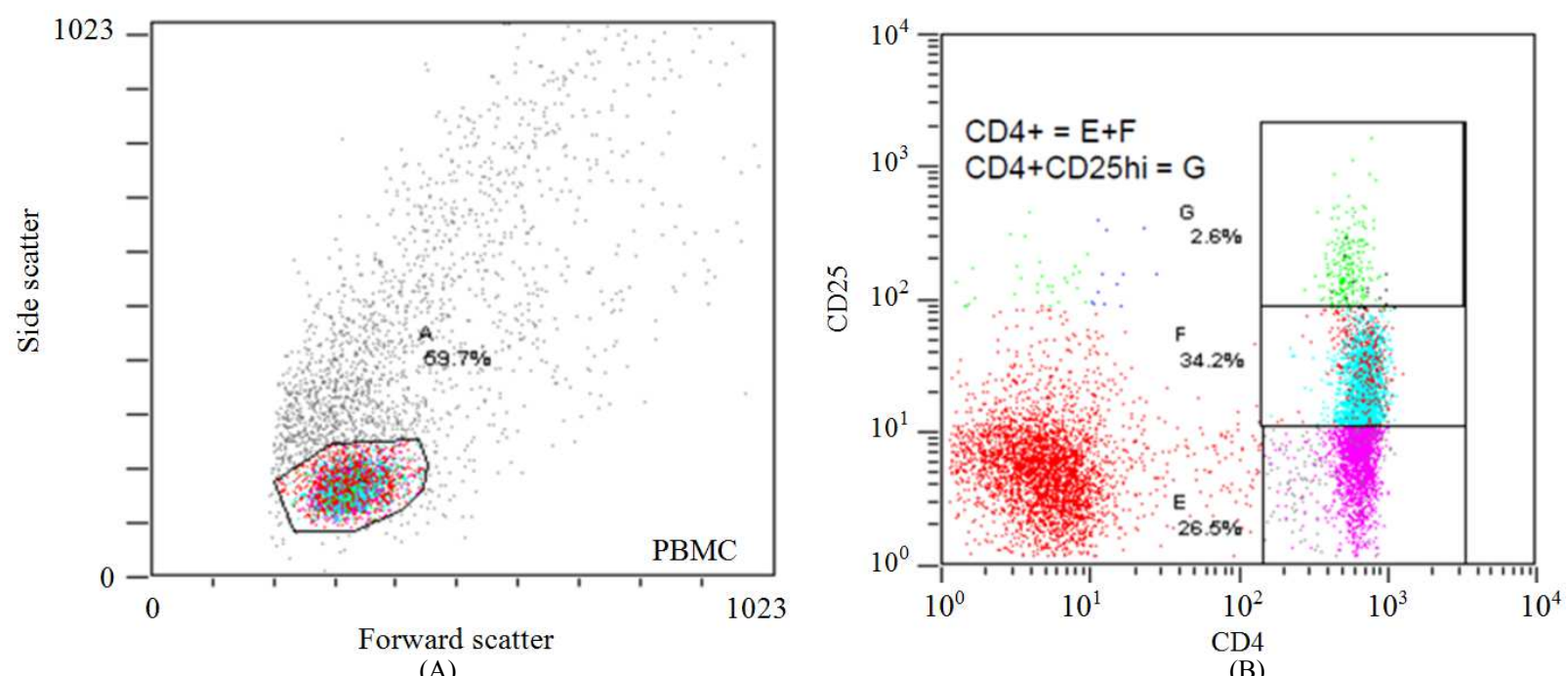

(A)

(B)
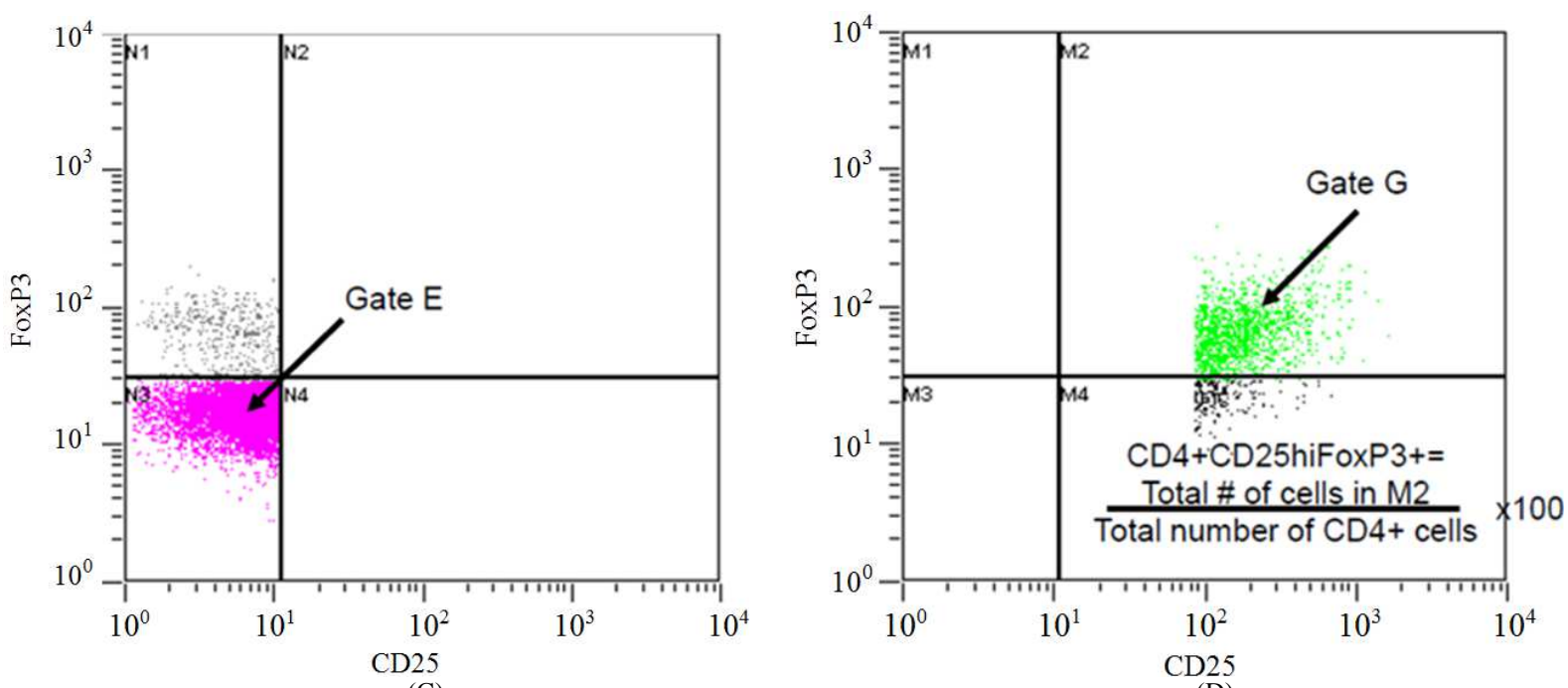

(C)

(D)

Fig. 1. Representative flow cytometry dot plots. PBMC (A) were analyzed for $\mathrm{C} 4$ and $\mathrm{CD} 25$ expression (B) $\mathrm{CD} 4^{+} \mathrm{CD} 25^{-}$and $\mathrm{CD} 4{ }^{+} \mathrm{CD} 25^{\mathrm{hi}}$ were then analyzed for FoxP3 expression (C and D)

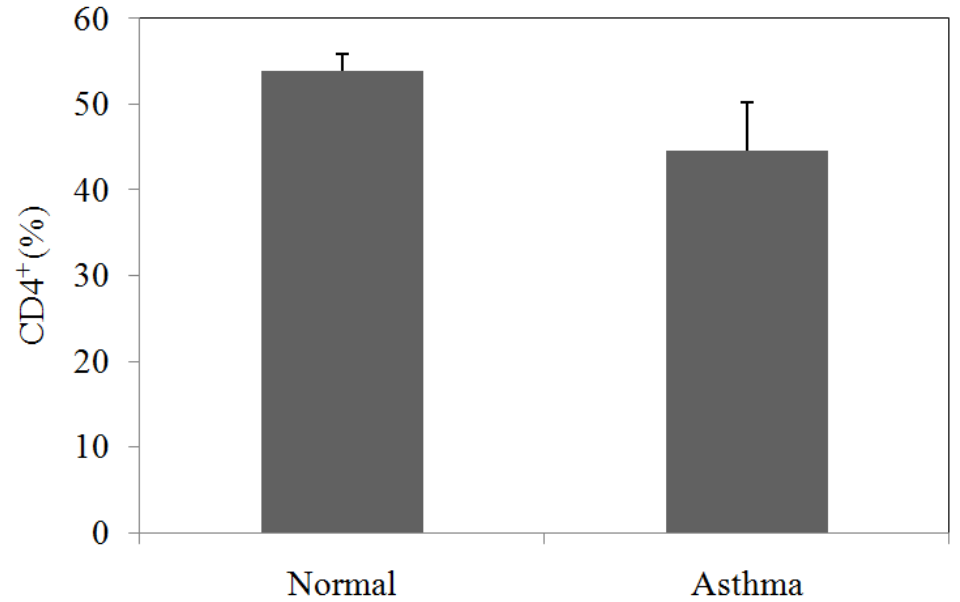

(A) 


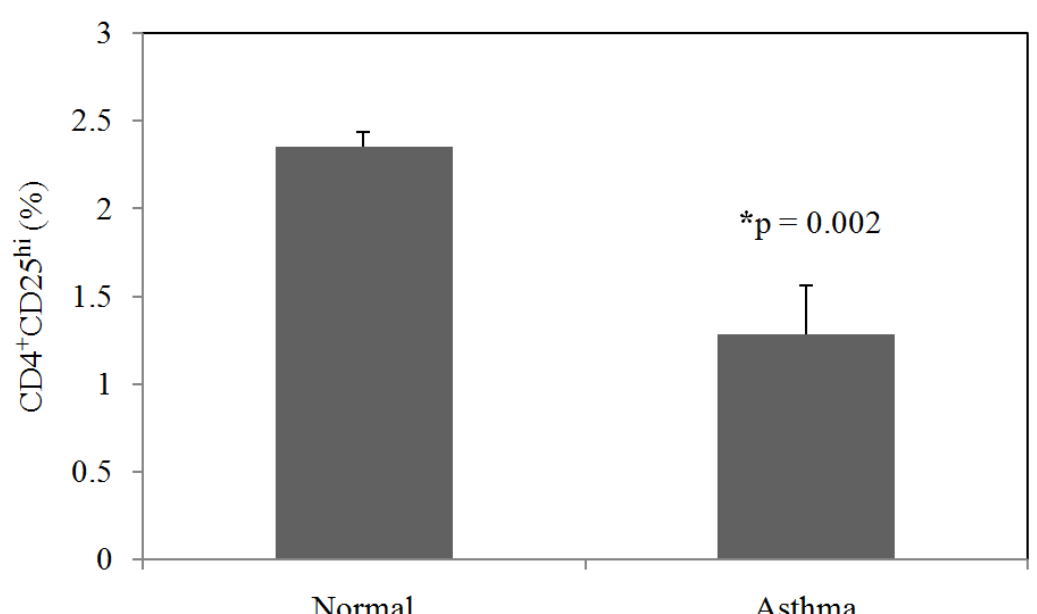

(B)

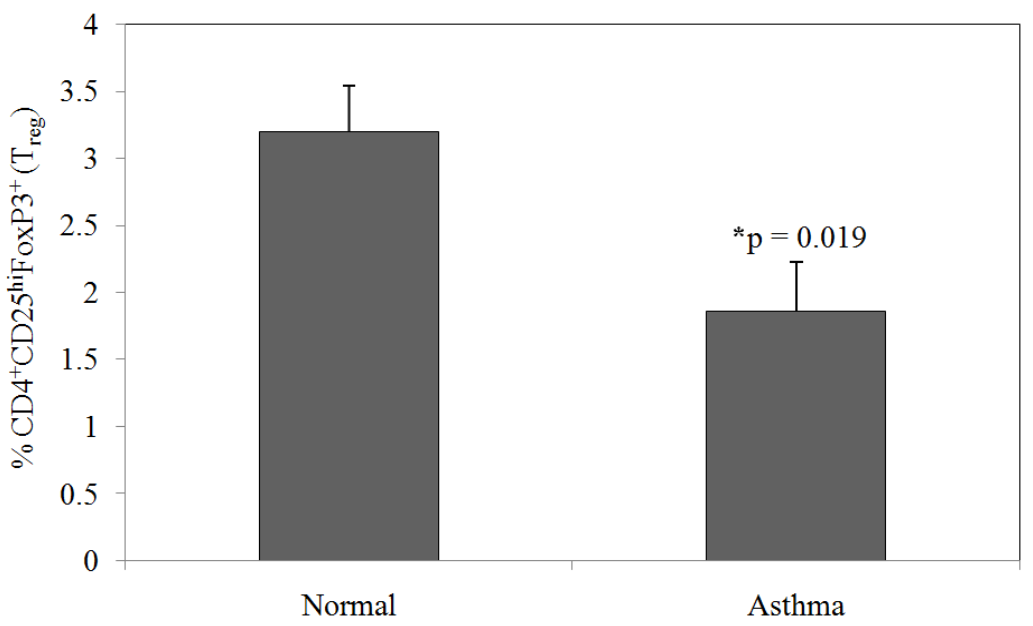

(C)

Fig. 2. T cell subpopulations in asthma patients and normal controls. Comparison of the percentage of $\mathrm{CD} 4^{+}(\mathrm{A}) \mathrm{CD} 4^{+} \mathrm{CD} 25^{\mathrm{hi}}(\mathrm{B})$ and $\mathrm{CD} 4{ }^{+} \mathrm{CD} 25^{\text {hi }} \mathrm{FoxP}^{+}(\mathrm{C})$ in the PBMC of asthma patients and normal controls. ${ }^{*} \mathrm{p}<0.05$

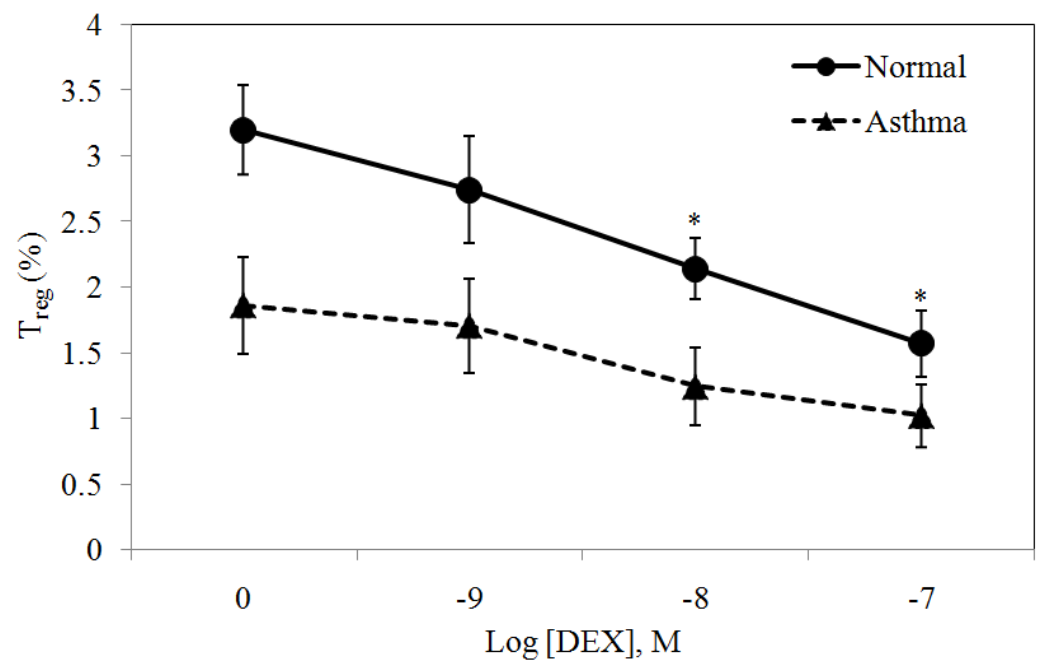

Fig. 3. Effects of short-term DEX incubation on $\mathrm{T}_{\text {reg }}$ numbers in asthma patients and normal controls. PBMC were incubated for 24 $\mathrm{h}$ with $10^{-9}, 10^{-8}$ and $10^{-7} \mathrm{M} \mathrm{DEX}$ and then $\mathrm{CD} 4^{+} \mathrm{CD} 25^{\mathrm{hi}} \mathrm{FoxP} 3^{+}$cells $\left(\mathrm{T}_{\text {reg }}\right)$ were quantified by flow cytometry. ${ }^{*} \mathrm{p}<0.05$ 


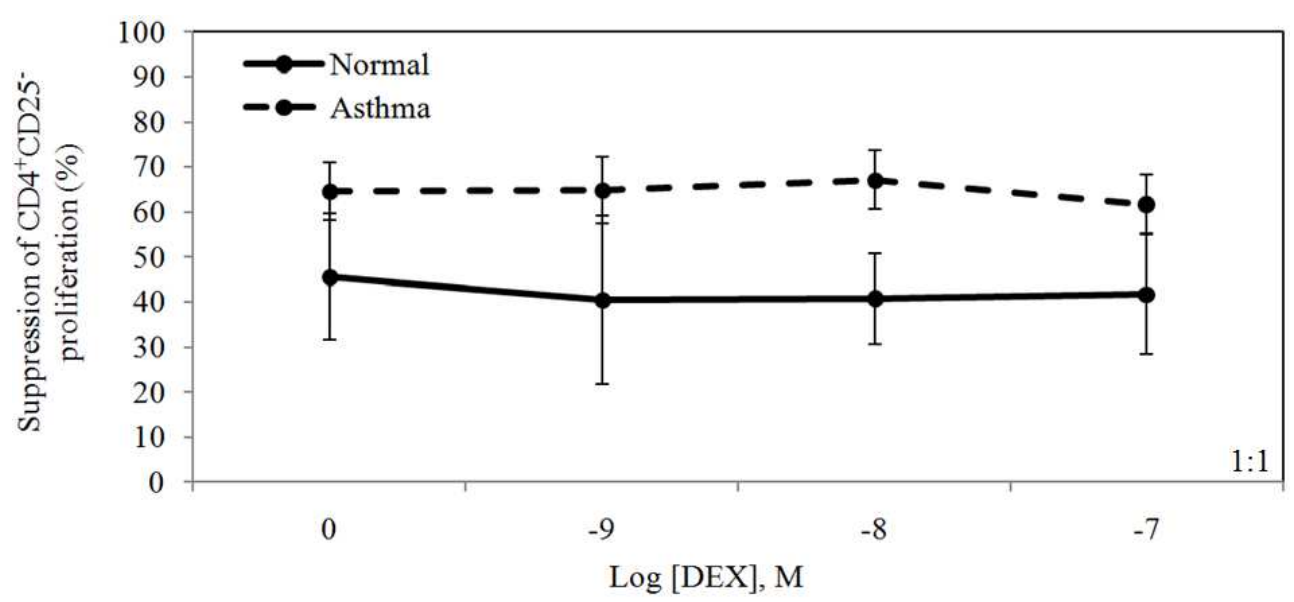

(A)

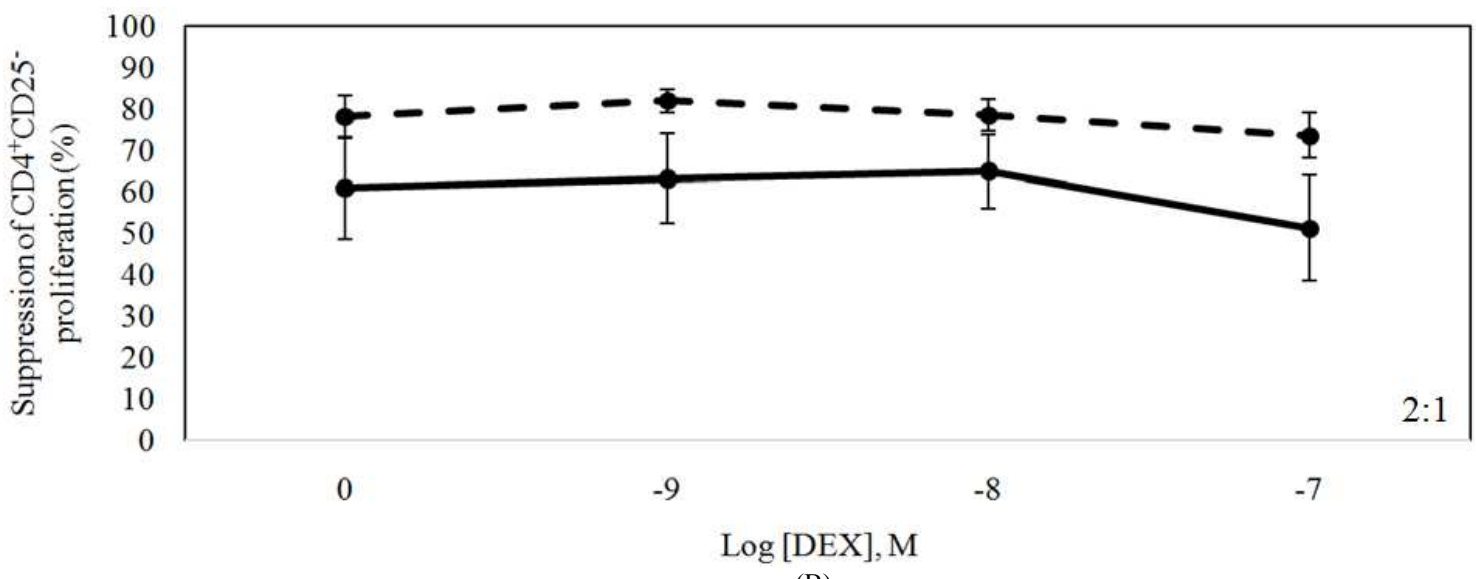

(B)

Fig. 4. Effects of short-term DEX incubation on $\mathrm{CD} 4^{+} \mathrm{CD} 25^{+} \mathrm{T}$ cell function. PBMC were incubated for $24 \mathrm{~h}$ with $10^{-9}, 10^{-8}$ and $10^{-7} \mathrm{M} \mathrm{DEX}$ and then $\mathrm{CD} 4^{+} \mathrm{CD} 25^{+}$cells and $\mathrm{CD} 4^{+} \mathrm{CD} 25^{-}$cells were isolated and added to culture at both 1:1 (A) and 2:1(B) ratios. $\mathrm{CD}^{+} \mathrm{CD} 25^{+}$cells from asthma patients and normal controls did not differ in their ability to suppress $\mathrm{CD} 4^{+} \mathrm{CD} 25^{-}$proliferation

$\underline{\text { Table 1. Participant characteristics }}$

\begin{tabular}{lll}
\hline & Normal $(\mathrm{n}=8)$ & Asthma $(\mathrm{n}=7)$ \\
\hline Age $(\mathrm{yrs})$ & $37.1(9.5)$ & $36.3(11.5)$ \\
BMI $\left(\mathrm{kg} / \mathrm{m}^{2}\right)$ & $27.5(4.3)$ & $31.9(8.9)$ \\
Gender & & \\
$\begin{array}{l}\text { Female } \\
\text { Male }\end{array}$ & $7(88 \%)$ & $5(71 \%)$ \\
Race & $1(12 \%)$ & $2(29 \%)$ \\
Caucasian & $5(63 \%)$ & $4(57 \%)$ \\
African American & $3(37 \%)$ & $3(43 \%)$ \\
\hline
\end{tabular}

Values are expressed as mean (SD) for continuous variables and $\mathrm{n}(\%)$ for categorical data

Effects of DEX on the Ability of $C D 4^{+} C D 25^{+}$ Regulatory $T$ Cells to Inhibit Proliferation of Conventional $T$ Cells in Normal and Asthma Subjects

We next performed add-back experiments to determine if $\mathrm{T}_{\text {reg }}$ function was affected by short-term incubation with DEX and whether any effect was different between asthmatics and normal controls. DEX at any concentration had no significant effect on the ability of $\mathrm{CD}^{+} \mathrm{CD} 25^{+} \mathrm{T}$ cells to suppress the proliferation of the $\mathrm{CD}^{+} \mathrm{CD} 25^{-} \mathrm{T}$ cells in either population compared to the No DEX control (Fig. 4). In the No DEX group, addition of one $\mathrm{CD} 4{ }^{+} \mathrm{CD} 25^{+} \mathrm{T}$ cell for every one $\mathrm{CD} 4^{+} \mathrm{CD} 25^{-}$cell resulted in a $46 \%$ reduction in proliferation of $\mathrm{CD} 4^{+} \mathrm{CD} 25^{-}$cells in the normal controls and a $65 \%$ reduction in proliferation of $\mathrm{CD} 4^{+} \mathrm{CD} 25^{-}$cells in the asthma group (compared to the proliferation of $\mathrm{CD} 4^{+} \mathrm{CD} 25^{-}$cells incubated without $\mathrm{CD} 4^{+} \mathrm{CD} 25^{+}$cells) (Fig. 4A). Although this was a fairly large difference, it did not reach statistical significance $(\mathrm{p}=0.258)$. There was a borderline significant difference $(\mathrm{p}=0.059)$ in suppression capability between the asthmatic population $(67 \%)$ versus the control population $(40 \%)$ at the stress-physiologic $\left(10^{-8}\right.$ M) DEX dose when the $\mathrm{CD} 4^{+} \mathrm{CD} 25^{-}$and $\mathrm{CD} 4^{+} \mathrm{CD} 25^{+}$ 
cells were added at a $1: 1$ ratio. There were no differences in $T_{\text {reg }}$ functionality between asthmatics and normal controls observed at either the $10^{-9} \mathrm{M}(\mathrm{p}=$ $0.263)$ or $10^{-7} \mathrm{M}(\mathrm{p}=0.221)$ DEX concentrations. There were no significant differences between asthma and normal controls when twice the number of $\mathrm{CD} 4{ }^{+} \mathrm{CD} 25^{+} \mathrm{T}_{\text {reg }}$ cells were added to the $\mathrm{CD} 4{ }^{+} \mathrm{CD} 25^{-}$ cell cultures (Fig. 4B). $\mathrm{CD}^{+} \mathrm{CD} 25^{+} \mathrm{T}$ cells were stimulated with beads in the absence of $\mathrm{CD} 4^{+} \mathrm{CD} 25^{-}$ cells and did not show a proliferative response (data not shown), indicating that these cells were not activated by the beads used in this assay.

\section{Discussion}

Stressful life events have been associated with an increased incidence and activity of inflammatory-based diseases such as asthma. Stress has been associated with the onset of asthma symptoms (Wright et al., 2004), the enhancement of skin test reactivity to allergens (Kiecolt-Glaser et al., 2009) and increased feelings of breathlessness (Rietveld et al., 1999). Our group has been interested in the effects of both chronic and acute stress hormone exposure on cells associated with the asthma phenotype for the past 15 years. In an 11-day tetanus culture, DEX decreases the production of IFN $\gamma($ a Th1 cytokine) and concomitantly increases the production of IL4 (a Th2 cytokine) (Salicru et al., 2007), which is consistent with the mechanisms involved in the etiology and severity of asthma. We hypothesized that this DEX-induced Th1/Th2 immune dysregulation may be due to alterations in $T_{\text {reg }}$ numbers and/or function since $\mathrm{T}_{\text {reg }}$ are known to regulate the balance between Th1 and Th2 effector cytokines (Ray et al., 2010).

In this study, we compared both the number and function of regulatory $T$ cells in a group of asthmatics with a group of non-asthmatic controls. We also characterized the effects of short term stress hormone exposure on both $\mathrm{T}_{\text {reg }}$ number and function in these populations. We found that asthmatics had significantly less $\mathrm{CD} 4{ }^{+} \mathrm{CD} 25^{\mathrm{hi}}$ and $\mathrm{CD} 4{ }^{+} \mathrm{CD} 25^{\mathrm{hi}} \mathrm{FoxP}^{+} \mathrm{T}$ cells than the normal controls. In addition, we found that $T_{\text {reg }}$ number was more dramatically decreased by DEX in the normal group compared to the asthma group. Finally, we report that $\mathrm{T}_{\text {reg }}$ function was not different between the normal and the asthma groups and that DEX had no effect on $\mathrm{T}_{\text {reg }}$ function. These data suggest that interventions that target expansion of the $T_{\text {reg }}$ compartment, either pharmacological or psychological, may be an effective strategy for treating asthma.

Asthma is characterized by changes to systemic immunity and some studies have indicated alterations in $\mathrm{T}_{\text {reg }}$ cell numbers as being important contributors to the asthma phenotype (Provoost et al., 2009; Lee et al., 2007). $T_{\text {reg }}$ are specialized cells that can broadly regulate the activity of other immune cells. It is thought that reduced numbers of $\mathrm{T}_{\text {reg }}$ in asthma have the downstream effect of an increase in Th2 activity. While this is a plausible hypothesis, there are other reports of no alterations in $\mathrm{T}_{\text {reg }}$ cells numbers in asthma (Bellinghausen et al., 2003; Shi et al., 2004; Sweilam et al., 2008). Conflicting reports on differences in the quantity of $\mathrm{T}_{\text {reg }}$ populations in asthma patients compared to controls may be due, at least in part, to differences in defining the $\mathrm{T}_{\text {reg }}$ population. Since $\mathrm{CD} 4^{+} \mathrm{CD} 25^{+/ \mathrm{hi}} \mathrm{T}$ cells (commonly used in defining $T_{\text {reg }}$ the population) may contain a mixture of $\mathrm{T}_{\text {reg }}$ and effector $\mathrm{CD} 4^{+} \mathrm{CD} 25^{-} \mathrm{T}$ cells, FoxP3 is now widely used as the most specific marker for $\mathrm{T}_{\text {reg }}$ in humans. Studies have indicated that both FoxP3 mRNA (Lin et al., 2008, Hartl et al., 2007) and protein expression (Provoost et al., 2009; Lluis et al., 2013) are reduced in asthma populations. Our data presented here are consistent with these studies.

$\mathrm{T}_{\text {reg }}$ numbers were affected by DEX incubation in both asthmatics and normal controls, although this effect was much less dramatic in the asthmatics. Previously, we have reported that DEX does not induce apoptosis in short term cell cultures (Agarwal and Marshall, 1998). For the normal controls, DEX reduced $\mathrm{T}_{\text {reg }}$ numbers significantly at the $10^{-8} \mathrm{M}$ dose, while the $\mathrm{T}_{\text {reg }}$ in the asthma group were only trending toward a significant reduction when incubated with the highest concentration of DEX $\left(10^{-7} \mathrm{M}\right)$. These data suggest that $\mathrm{T}_{\text {reg }}$ numbers in this population of asthma patients, while significantly lower than the normal controls, are not as susceptible to the effects of DEX. It is possible that stress levels in this group of asthma patients were higher than the normal controls. This higher level of stress (and resulting higher levels of circulating stress hormones) may have suppressed $\mathrm{T}_{\text {reg }}$ numbers in vivo, making these cells resistant to further suppression by ex vivo DEX. In support of this hypothesis, asthmatics have been shown to have higher stress levels when compared to healthy controls (Katon et al., 2004). Future experiments will determine the influence of stress levels and circulating in vivo stress hormones on $\mathrm{T}_{\text {reg }}$ numbers and whether this has an impact on altered $\mathrm{T}$ cell populations in asthma patients. A finding of a direct impact of in vivo stress levels on the cells involved in the path mechanisms of asthma would have significant clinical implications for the management of this disease.

While $T_{\text {reg }}$ number was significantly different between the two groups, $T_{\text {reg }}$ functionality was not. In addition, incubation with a range of DEX concentrations did not alter $T_{\text {reg }}$ function in either population. Impaired functionality of $\mathrm{T}_{\text {reg }}$ has been reported in asthma patients and is proposed as a potential mechanism for the defective Th2 response in asthma. These studies of the differences in $\mathrm{T}_{\text {reg }}$ functionality in asthma patients Vs. normal controls are difficult to compare due to 
differences in the specific model used to assess suppression. Hartl et al. (2007) isolated effector T cells and $\mathrm{T}_{\text {reg }}$ from the PBMC of normal and asthmatic children and stimulated the $\mathrm{CD} 4^{+} \mathrm{CD} 25^{-} \mathrm{T}$ cells with anti CD3, anti CD28 and IL4 and found no difference in the suppressive capacity of the $\mathrm{CD} 4^{+} \mathrm{CD} 25^{+} \mathrm{T}_{\text {reg }}$ between the two groups. Another study found that $\mathrm{T}_{\text {reg }}$ from the PBMC of asthma patients were functionally impaired when effector cells were stimulated with Der p3 extract (Lin et al., 2008). Although FoxP3 is the definitive marker for $T_{\text {reg, }}$ it is impossible to use in assays that separate $T_{\text {reg }}$ from effector $T$ cells due to its intracellular expression. Thus, each laboratory has its own methodology to isolate " $T_{\text {reg }}$ " based on a combination of CD4, CD25 and CD127 and these isolated " $\mathrm{T}_{\text {reg" }}$ are likely contaminated with varying numbers of effector cells that may skew the results of suppression assays and may partially account for discrepancies in the data between labs. We separated $\mathrm{CD} 4{ }^{+} \mathrm{CD} 25^{+} \mathrm{T}$ cells with a commonly used bead-based system and then activated effector cells with beads containing anti-CD2, -CD3 and -CD28. Activation of effector T cells with bead-bound antibody may not reflect the ability of the $T_{\text {reg }}$ to control the response to specific antigens and allergens. Our data show that function was not affected by DEX in either group. Interestingly, function was enhanced in asthma patients but this did not reach statistical significance in the No DEX cultures and was only borderline significant in the $10^{-8} \mathrm{M}$ DEX cultures. We hypothesize that Treg function may be slightly enhanced in this population to compensate for the reduced numbers, although our small sample size is certainly a limitation and a larger sample size is needed to fully explore this hypothesis. Whether these differences are due to differences in in vivo stress hormone levels is also a matter of future investigation.

\section{Conclusion}

This pilot study shows that $T_{\text {reg }}$ numbers are reduced while $\mathrm{T}_{\text {reg }}$ function is not different in asthma patients compared to a normal control group. Further, we show that $\mathrm{T}_{\text {reg }}$ from asthma patients are less dramatically affected by incubation with DEX. Delineating the cellular mechanisms that contribute to asthma and how modifiable risk factors (such as increased stress) can impact these mechanisms is crucial for the development of novel therapies. Future experimental therapies for asthma may target the expansion of the $T_{\text {reg }}$ population through stress management.

\section{Acknowledgement}

We would like to acknowledge Denise Montgomery and Sheila Belk for technical assistance and assistant with recruiting patients, respectively.

\section{Funding Information}

This study was funded by the University of Mississippi Medical Center Department of Medicine.

\section{Author Contributions}

Kristina E. Rehm conducted all of the assays and did all of the statistical analyses presented in this study. She also took the lead in preparing this manuscript. Gailen D. Marshall acted as a mentor to Kristina E. Rehm in designing the assays that are presented in this study. He also assisted Kristina E. Rehm in preparing the manuscript.

\section{Conflict of Interest}

The authors report no conflicts of interest. The authors alone are responsible for the content and writing of the paper.

\section{References}

Agarwal, S.K. and G.D. Marshall, Jr. 1998. Glucocorticoid-induced type 1/type 2 cytokine alterations in humans: A model for stress-related immune dysfunction. J. Interferon Cytokine Res., 18: 1059-68. DOI: 10.1089/jir.1998.18.1059

Baumann, S. and A. Lorentz, 2013. Obesity-a promoter of allergy? Int. Arch. Allergy Immunol., 162: 205-13. DOI: 10.1159/000353972

Bellinghausen, I., B. Klostermann, J. Knop and J. Saloga, 2003. Human CD4+CD25+ $\mathrm{T}$ cells derived from the majority of atopic donors are able to suppress $\mathrm{TH} 1$ and $\mathrm{TH} 2$ cytokine production. J. Allergy Clin. Immunol., 111: 862-8. PMID: 12704370

Brooks, C., N. Pearce and J. Douwes, 2013. The hygiene hypothesis in allergy and asthma: An update. Curr. Opin. Allergy Clin. Immunol., 13: 70-7. DOI: 10.1097/ACI.0b013e32835ad0d2

Chen, E., M.D. Hanson, L.Q. Paterson, M.J. Griffin and H.A. Walker et al., 2006. Socioeconomic status and inflammatory processes in childhood asthma: The role of psychological stress. J. Allergy Clin. Immunol., 117: 1014-20.

DOI: $10.1016 /$ j.jaci.2006.01.036

Chen, E. and G.E. Miller, 2007. Stress and inflammation in exacerbations of asthma. Brain Behav. Immunl., 21: 993-9. DOI: 10.1016/j.bbi.2007.03.009

Hartl, D., B. Koller, A.T. Mehlhorn, D. Reinhardt and T. Nicolai et al., 2007. Quantitative and functional impairment of pulmonary $\mathrm{CD}_{4}+\mathrm{CD}_{25}{ }^{\text {hi }}$ regulatory $\mathrm{T}$ cells in pediatric asthma. J. Allergy Clin. Immunol., 119: 1258-66. DOI: 10.1016/j.jaci.2007.02.023 
Hayden, M.L., 2007. Immunoglobulin E-mediated airway inflammation is active in most patients with asthma. J. Am. Acad. Nurse Pract., 19: 439-49. DOI: $10.1111 /$ j.1745-7599.2007.00251.x

Holgate, S.T., 2013. Mechanisms of asthma and implications for its prevention and treatment: A personal journey. Allergy Asthma Immunol. Res., 5: 343-7. DOI: 10.4168/aair.2013.5.6.343

Katon, W.J., L. Richardson, P. Lozano and E. McCauley, 2004. The relationship of asthma and anxiety disorders. Psychosom Med., 66: 349-55. PMID: 15184694

Kiecolt-Glaser, J.K., K.L. Heffner, R. Glaser, W.B. Malarkey and K. Porter et al., 2009. How stress and anxiety can alter immediate and late phase skin test responses in allergic rhinitis. Psychoneuroendocrinology, 34: 670-80. DOI: 10.1016/j.psyneuen.2008.11.010

Kudo, M., Y. Ishigatsubo and I. Aoki, 2013. Pathology of asthma. Front Microbiol., 4: 263-263.

DOI: $10.3389 /$ fmicb.2013.00263

Lee, J.H., H.H. Yu, L.C. Wang, Y.H. Yang and Y.T. Lin et al., 2007. The levels of $\mathrm{CD} 4^{+} \mathrm{CD} 25^{+}$regulatory $\mathrm{T}$ cells in paediatric patients with allergic rhinitis and bronchial asthma. Clin. Exp. Immunol., 148: 53-63. DOI: $10.1111 / \mathrm{j} .1365-2249.2007 .03329 . \mathrm{x}$

Lin, Y.L., C.C. Shieh and J.Y. Wang, 2008. The functional insufficiency of human $\mathrm{CD} 4^{+} \mathrm{CD} 25^{\text {high }} \mathrm{T}$ regulatory cells in allergic asthma is subjected to TNF- $\alpha$ modulation. Allergy, 63: 67-74. DOI: $10.1111 / \mathrm{j} .1398-9995.2007 .01526 . x$

Lluis, A., M. Depner, B. Gaugler, P. Saas and V.I. Casaca et al., 2013. Increased regulatory $\mathrm{T}$-cell numbers are associated with farm milk exposure and lower atopic sensitization and asthma in childhood. J. Allergy Clin. Immunol., 133: 551-559. DOI: 10.1016/j.jaci.2013.06.034

Lockett, G.A. and J.W. Holloway, 2013. Genome-wide association studies in asthma; perhaps, the end of the beginning. Curr. Opin. Allergy Clin. Immunol., 13: 463-9. DOI: 10.1097/ACI.0b013e328364ea5f

Murdoch, J.R. and C.M. Lloyd, 2010. Chronic inflammation and asthma. Mutat. Res., 690: 24-39. DOI: $10.1016 /$ j.mrfmmm.2009.09.005

Pokladnikova, J. and I. Selke-Krulichova, 2013. Effectiveness of a comprehensive lifestyle modification program for asthma patients: A randomized controlled pilot trial. J. Asthma, 50: 318-26. DOI: 10.3109/02770903.2012.759587

Provoost, S., T. Maes, Y.M. van Durme, P. Gevaert and C. Bachert et al., 2009. Decreased FOXP3 protein expression in patients with asthma. Allergy, 64: 1539-46. DOI: 10.1111/j.1398-9995.2009.02056.x

Ray, A., A. Khare, N. Krishnamoorthy, Z. Qi and P. Ray, 2010. Regulatory $\mathrm{T}$ cells in many flavors control asthma. Mucosal Immunol., 3: 216-29. DOI: 10.1038/mi.2010.4
Rehm, K.E., R.F. Connor, G.J. Jones, K. Yimbu and R.L. Roper, 2010. Vaccinia virus A35R inhibits MHC class II antigen presentation. Virology, 397: 176-86. DOI: 10.1016/j.virol.2009.11.008

Rehm, K.E., L. Xiang, O.U. Elci, M. Griswold and G.D. Marshall, Jr. 2012. Variability in laboratory immune parameters is associated with stress hormone receptor polymorphisms. Neuroimmunomodulation, 19: 220-8. DOI: 10.1159/000334711

Rietveld, S., I. van Beest and W. Everaerd, 1999. Stressinduced breathlessness in asthma. Psychol. Med., 29: 1359-66. DOI: 10.1017/S0033291799008958

Sakaguchi, S., K. Wing, Y. Onishi, P. Prieto-Martin and T. Yamaguchi, 2009. Regulatory T cells: How do they suppress immune responses? Int. Immunol., 21: 1105-11. DOI: 10.1093/intimm/dxp095

Salicru, A.N., C.F. Sams and G.D. Marshall, 2007. Cooperative effects of corticosteroids and catecholamines upon immune deviation of the type1/type-2 cytokine balance in favor of type-2 expression in human peripheral blood mononuclear cells. Brain Behav. Immunl., 21: 913-20. DOI: 10.1016/j.bbi.2007.02.006

Shi, H.Z., S. Li, Z.F. Xie, X.J. Qin and X. Qin et al., 2004. Regulatory $\mathrm{CD} 4^{+} \mathrm{CD} 25^{+} \mathrm{T}$ lymphocytes in peripheral blood from patients with atopic asthma. Clin. Immunol., 113: 172-8. DOI: 10.1016/j.clim.2004.06.009

Sweilam, M., A. Helmy, J.A. El-Sharnoby, A. ElBendary and A.A. Erfan et al., 2008. Role of Foxp3 and regulatory $\mathrm{CD} 4+\mathrm{CD} 25+\mathrm{T}$-lymphocytes in bronchial asthma. Egypt J. Immunol., 15: 113-23. PMID: 20306694

Thomson, N.C., R. Chaudhuri and E. Livingston, 2004. Asthma and cigarette smoking. Eur. Respir. J., 24: 822-33. DOI: 10.1183/09031936.04.00039004

Vent-Schmidt, J., J.M. Han, K.G. Macdonald and M.K. Levings. 2013. The role of FOXP3 in regulating immune responses. Int. Rev. Immunol., 33: 110-128. DOI: $10.3109 / 08830185.2013 .811657$

Wright, R.J., H. Mitchell, C.M. Visness, S. Cohen and J. Stout et al., 2004. Community violence and asthma morbidity: The inner-city asthma study. Am. J. Public Health, 94: 625-32. DOI: 10.2105/AJPH.94.4.625

Xiang, L. and G.D. Marshall, Jr. 2011. Immunomodulatory effects of in vitro stress hormones on FoxP3, Th1/Th2 cytokine and costimulatory molecule mRNA expression in human peripheral blood mononuclear cells. Neuroimmunomodulation, 18: 1-10. DOI: $10.1159 / 000311450$ 